\title{
Durkheim and the Social Functions of Sacred Music
}

\author{
JONATHAN L. FRIEDMANN \\ $3^{\text {rd }}$ Year MA, Jewish Sacred Music \\ Academy for Jewish Religion \\ Los Angeles, California
}

\section{Introduction}

"Music is the most social of the arts," wrote Edward Dickinson, "not only because it is the most universally beloved, but because it affords the largest opportunities for cooperation."1 The social nature of musical production is evident throughout history and across cultures, and lies at the root of the anthropological definition of music itself. As ethnomusicologist Alan Merriam concluded from his study of the Basongye people of the Congo, music differs from other sounds in that it is a uniquely human phenomenon, consists of patterned and continuous sounds, and is dependent on the combined effort of performers and audience. ${ }^{2}$ Historically, rather than being an end in itself, music has most often served as an accompaniment to other, nonmusical social events. It has even been argued that music's original and still most valuable role is as an aid to religious worship. ${ }^{3}$

The pervasive union of music and religion can be explained, at least in part, by the fact that religion, like music, is a social phenomenon. It is the shared experience of doing religion that makes it more than just a set of beliefs. In the contemporary West, this important distinction between believing and doing has found expression with those who, choosing to distance

\footnotetext{
${ }^{1}$ Edward Dickinson, "Oratorio Performance in Europe and America," in The American History and Encyclopedia of Music, ed. W. L. Hubbard (New York: Irving Squire, 1909), 1.

2 Alan P. Merriam, "The Arts and Anthropology," in Anthropology and Art: Readings in CrossCultural Aesthetics, ed. Charlotte M. Otten (Austin, TX: University of Texas Press, 1971), 93105.

${ }^{3}$ Paul Honigsheim, Sociologists and Music: An Introduction to the Study of Music and Society (New Brunswick, NJ: Transaction Publishers, 1989), 60.
} 
themselves from organized religion, claim to be "spiritual, but not religious." 4 The communal character of religion is displayed most clearly in public worship, which in virtually every tradition includes some form of musical accompaniment. ${ }^{5}$

Missing, however, from this general explanation of the widespread use of sacred music is an appreciation of how such music actually serves social purposes. After all, there is only so much to be gained from the general observation that music and religion are linked because they are both essentially social enterprises. Yet, while scholars readily admit that sacred music is vital to the religious experience, their basis for this claim is often theological rather than sociological. One is more likely to come across studies focusing on music as the language of the soul, ${ }^{6}$ for instance, than theoretical approaches to the social import of sacred song. Likewise, when the social value of ritual music is addressed, it is usually tinged with spiritual justification, such as music's ability to symbolically transport the worshiping community into mystical awareness. $^{7}$

This is not to say that theology and spirituality are unimportant to the partnership of music and religion. Music enhances liturgical texts, and can heighten one's attentiveness during prayer. Through a combination of pitches, rhythms, timbres, durations, and dynamics, music can “unlock the most hidden contents of [one's] spiritual and emotional being." 8 As Protestant

\footnotetext{
${ }^{4}$ See Robert C. Fuller, Spiritual, but not Religious: Understanding Unchurched America (New York: Oxford University Press, 2001).

${ }^{5}$ Robert S. Ellwood, Introducing Religion from Inside and Outside, 2nd ed. (Upper Saddle River, NJ: Prentice Hall, 1983), 110.

${ }^{6}$ Don E. Saliers, Music and Theology (Nashville, TN: Abingdon Press, 2007), 4.

${ }^{7}$ Stephen A. Marini, Sacred Song in America: Religion, Music, and Public Culture (Urbana and Chicago: University of Illinois Press, 2003), 7.

${ }^{8}$ Nicholas Cook, A Guide to Musical Analysis (London: Oxford University Press, 1987), 1.
} 
theologian R. Heber Newton wrote, "'Holy Music' makes perfectly clear this faith of the human heart, which is the corollary of the faith in God."9

Still, a truly comprehensive understanding of sacred music must also take into account music's social dimension. It is thus the purpose of this paper to present a social-theoretical approach to sacred song. In particular, I will apply sociologist Émile Durkheim's discussion of ceremonial ritual to the use of music in Jewish and Christian worship, focusing on how such music serves disciplinary, cohesive, revitalizing, and euphoric functions. ${ }^{10}$ It is my hope that such an analysis will yield a useful framework from which to address the oft-neglected topic of the social functions of sacred music.

\section{Durkheim on the Sacred Experience}

In The Elementary Forms of Religious Life (1912), Durkheim defined religion as a system of beliefs and practices that "unite[s] its adherents in a single moral community called a church." 11 In this way, he distinguished between religion and magic, pointing out that, while magic "does not bind its followers to one another and unite them in a single group living the same life," ${ }^{12}$ religion is never found without a church. ${ }^{13}$ Such "churches" are, according to Durkheim, assemblages of individuals bound together by shared beliefs, unified standards of character and practice, and common conceptions of the sacred and its relation to the profane. ${ }^{14}$

\footnotetext{
${ }^{9}$ R. Heber Newton, The Mysticism of Music (New York: Putnam, 1915), 35.

${ }^{10}$ These four social functions of ceremonial ritual are summarized in Harry Alpert's book, Emile Durkheim and His Sociology (New York: Russell and Russell, 1961), 198-203.

${ }^{11}$ Émile Durkheim, The Elementary Forms of Religious Life, trans. Carol Cosman (New York: Oxford University Press, 2001), 46.

12 Ibid., 43.

${ }^{13}$ Ibid., 42

${ }^{14}$ Ibid.
} 
And, he argued, the most effective way to achieve and maintain this necessary cohesion is through the performance of ritual. ${ }^{15}$

It should be noted, however, that Durkheim's interpretation of the sacred experience differs significantly from that of most who engage in religious ritual - particularly those dedicated to composing and performing sacred music. Durkheim agreed with philosopher William James that the religious experience is an authentic force in one's life, ${ }^{16}$ but he was unwilling to privilege the believers' explanation of their own experience. Instead, he acknowledged that while sacred power exists, this power is the community itself, and not an autonomous, objective reality. Put simply, Durkheim believed the sacred experience to be little more than the dynamic energy produced when people get together.

Even so, Durkheim refrained from disparaging those who affirm religious convictions. As scholar J. Samuel Preus explained, Durkheim maintained that "religious actors are not deceived in their conviction that they were in the embrace of powers larger and more profound than reason," but rather that the "believers do not understand the real grounds of their convictions." 17 For Durkheim, this "real ground" is collective effervescence: the perceptible energy of a group engaged in a ritual practice, which is often interpreted as "sacred."

Durkheim's theory offers profound insights into the social nature of religion. It is, after all, quite evident that genuine collective forces emerge when individuals gather around a particular idea or cause. There is a certain "electricity" found among groups united in solidarity. But critics have pointed out that the palpable force of a group gathered around common convictions does not take into consideration the complexities of the individual's experience of

\footnotetext{
${ }^{15}$ Ibid., xiv.

${ }^{16}$ See William James, The Varieties of Religious Experience (New York: Mentor Books, 1958).

${ }^{17}$ J. Samuel Preus, Explaining Religion: Criticism and Theory from Bodin to Freud (Atlanta, GA: Scholars Press, 1996), 162
} 
the sacred. ${ }^{18}$ Durkheim's theory cannot speak adequately to personal sacred experiences that occur outside of social settings. For example, St. Paul's conversion in the New Testament and Buddha's enlightenment under the Bodhi Tree were spiritual episodes that ran counter to social norms. Yet, to be fair, while Durkheim recognized the significance of individualism, he concerned himself almost exclusively with group behavior. ${ }^{19}$

\section{Music and Ceremonial Ritual}

Most important for this study is Durkheim's emphasis on the social import of ceremonial ritual. Durkheim observed that ceremonial ritual embodies those qualities he believed to constitute the sacred: "collective states, common traditions and emotions, (and) feelings that have a relationship to objects of general interest." ${ }^{20}$ He delineated four specific social functions of ritual, each of which is relevant to the study of sacred music.

First, ceremonial ritual serves a disciplinary function, imparting principles of belief and behavior through highly patterned liturgical speech and actions. Within the context of worship, music is perhaps the most effective mode of communicating such messages. Particularly in the hymn traditions of Christianity, concise verses are used to convey ethical and theological viewpoints argued elsewhere, or to emphasize religious themes such as praise, commitment, longing, and lament. ${ }^{21}$ Through careful partnership of music and words, an effective song can

\footnotetext{
${ }^{18}$ See, for instance, Steven Lukes, Emile Durkheim: His Life and Work (New York: Harper and Row, 1972), 481.

${ }^{19}$ Durkheim, The Elementary Forms of Religious Life, 45-6.

${ }^{20}$ Émile Durkheim, "Concerning the Definition of Religious Phenomena," in Durkheim on Religion, ed. W. F. K. Pickering (London: Routledge and Kegan Paul, 1975), 95.

${ }^{21}$ Brian Wren, Praying Twice: The Music and Words of Congregational Singing (Louisville, KY: Westminster John Knox Press, 2005), 369.
} 
capture succinctly the essence of both religious ideas and the sacred moment, producing what has been called a "theological miniature.",22

Sam L. Jacobson, in his 1898 article, "The Music of the Jews," traced this disciplinary function of sacred song to ancient times: "The early priesthood studied and practiced music with consummate skill. Bringing the guiding light of religion to the people, teaching being their sphere of industry, they were ever seeking the best means of inculcating the lessons of Judaism; music naturally proved of greatest assistance, being part of the natural language of mankind." For Jacobson, evidence of music's value as a teaching tool is seen in the fact that, "Even today, pedagogy knows no more potent means of instilling an idea into the youthful mind than by association with music, and it is generally conceded that a text garbed in appropriate music is more readily grasped, assimilated and remembered than is one in the form of a plain statement.",23

Second, Durkheim found that ceremonial ritual provides a cohesive function, bringing people together, reaffirming social bonds, and bolstering congregational solidarity. This function can also be achieved through sacred music. In the Jewish synagogue, congregations often sing Hinei Ma Tov, a liturgical text taken from Psalm 133: "How good and how pleasant that brothers dwell together." Sung to a variety of melodies, the message of Hinei Ma Tov supports quite literally the cohesive function of prayer-song. With it, the congregation affirms, at least implicitly, an underlining assumption of shared values and beliefs — what Durkheim understood as the basis of religious "brotherhood." 24

\footnotetext{
${ }^{22}$ Saliers, Music and Theology, 37.

${ }^{23}$ Sam L. Jacobson, "The Music of the Jews," Music: A Monthly Magazine 14 (1898): 412.

${ }^{24}$ Durkheim, The Elementary Forms of Religious Life, 42-3.
} 
The cohesive function of ritual music is also evident within congregations that seek to uphold a certain "culture." Christian renewal churches, for example, cater largely to the needs of baby boomers seeking open, friendly, and deep relationships both with each other and with the divine. Their worship services incorporate pop-style music — often performed by elaborate bands - that helps to demarcate the congregants both from other churches and as a fellowship of Christians desiring new and personally meaningful experiences of God. ${ }^{25}$ As hymn writer Jack Hayford explains, "New musical expression is fitting as we each discover new things about the manifold wisdom of the Lord our God."26

Third, Durkheim found that ceremonial ritual serves a revitalizing function, reminding the community of its shared history and common heritage. In the Jewish tradition, this is perhaps best demonstrated by the widespread use of Misinai tunes: melody-types traditionally believed to have been transmitted to Moses on Sinai. ${ }^{27}$ In actuality, we have no definitive record of music from the days of Moses; but Misinai melodies do have a long history, developing in southern Germany and eastern France between the eleventh and fifteenth centuries C.E. These quintessential Ashkenazi themes have come to dominate the music of Rosh Hashanah (New Year) and Yom Kippur (Day of Atonement), and virtually all Ashkenazi Jews throughout the world hear these melodies during the High Holy Days. These ubiquitous sounds unite Jews who might otherwise be religiously or geographically dispersed. They are an audible ritual expression of a collective past.

${ }^{25}$ Elmer Towns, Putting an End to Worship Wars (Nashville, TN: Broadman and Holdman Publishers, 1997), 81-89.

${ }^{26}$ Jack Hayford, Worship His Majesty (Waco, TX: World Book Publisher, 1987), 144.

27 The Hebrew term Misinai is an abbreviation of the designation Halakhah Lemosheh Missinai- "having been transmitted from Moses on Mount Sinai." 
The great effort to preserve these melodies reflects the importance placed on historical continuity and group solidarity within Jewish tradition. Eastern European Jews, for instance, gave these tunes the elevated status of skarbova, meaning "antique" or "old." More specifically, the word refers the music's "official" status, indicating that, from the time of their genesis to the present, they are considered obligatory in the High Holy Day services; no other melodies may be substituted for them. Jewish musicologist Macy Nulman described the purpose and lasting effect of codifying this music: "To this day, these melodies that stir the heart and infuse awe and devotion in one's prayer, are essential elements of the synagogue service and remain a unifying force in Jewish life." ${ }^{28}$ In a very real sense, then, Misinai tunes serve a revitalizing function, providing Jews a link both to the divine and a shared sacred past, and announcing to the community that "What we do has a history; we ourselves have a history."29

Fourth, Durkheim explained that ceremonial ritual has a euphoric function, inspiring among worshipers a pleasant feeling of social wellbeing. Sociologist Ronald L. Johnstone notes that this function of ritual takes on special significance when a group is faced with instability, disappointment, or calamity. "It helps to straighten out the sharp curves," Johnstone writes, “and adds some rays of light in the dark tunnels of disappointment and despair." 30 To be sure, the need for music that fulfills this function varies depending on the condition of the community. There is, indeed, a long history of singing in the face of adversity. For centuries, the hardships of war, persecution, and varied forms of discrimination have inspired songs of witness and hope.

\footnotetext{
${ }^{28}$ Macy Nulman, Concepts of Jewish Music and Prayer (New York: Yeshiva University Press, 1985), 29.

${ }^{29}$ Ronald L. Johnstone, Religion in Society: A Sociology of Religion (Upper Saddle River, NJ: Prentice Hall,1997), 31.

${ }^{30}$ Ibid.
} 
This is illustrated by a first-hand account of Yom Kippur in the Nazi-occupied ghetto of

Kovno, Lithuania, where a determined cantor brought heightened spirituality and a sense of normalcy — the dual aspects of Durkheim's ritual euphoria — to his small congregation:

In the same year in which the Germans had occupied Kovno, prayer groups were organized in the ghetto for the High Holy Days, and one such group met in the hospital. In the middle of Yom Kippur, in fact in the middle of the musaf [additional] service when the cantor and the participants poured out their hearts in prayer, a rumor suddenly spread that two German officials from the "Staatskommissariat" had entered the ghetto and were going in the direction of the hospital. The hospital was notified at once and just as in the time of the Spanish Inquisition, every trace of the "major crime" momentarily disappeared. The Holy Ark was hidden, the burning Yom Kippur candles were extinguished, the prayer books were hidden, and the participants were hidden in a separate room. The two Germans inspected the hospital for some time but they found nothing suspicious. After they left everything and everyone returned to their place and the musaf service continued until its conclusion. ${ }^{31}$

The euphoric function of sacred song was similarly evident in the black HolinessPentecostal churches of Brooklyn in the early 1900s. These churches stressed a doctrine of otherworldliness, which encouraged members to divorce themselves from secular activities and strive for a life free of sin. This idealized detachment from worldly things was largely a response to the attempted dehumanization of blacks by the white population. As Clarence Taylor wrote in The Black Churches of Brooklyn, "Black Holiness-Pentecostal culture countered the cultural hegemonic order by promoting a theory of human value giving African Americans an alternative avenue to gain status and self-esteem." ${ }^{, 32}$

\footnotetext{
${ }^{31}$ Fred S. Heuman, trans., "Prayer and the Sheliach Tzibbur During the Holocaust," Journal of Jewish Music and Liturgy 3 (1985-86): 55.

${ }^{32}$ Clarence Taylor, The Black Churches of Brooklyn (New York: Columbia University Press, 1994), 38.
} 
Out of this need for self-worth and community stability in the face of prejudice grew a corpus of sacred songs that would come to be identified as early gospel music. These songs required the full participation of church members, encouraging call and response between choir and congregation, ecstatic and spontaneous shouting and clapping, and joyous dancing.

The music of the black Holiness-Pentecostal churches reflected the community's need to transcend the hardships of life, and to attain a sense of ritual euphoria. Many of the texts that were set to music had a therapeutic quality, aimed at relieving the hardships of the poor by promising a better life if they put their trust in the Lord. Moreover, while earlier slave spirituals drew heavily on the Old Testament for inspiration, these songs focused mainly on Jesus' role in salvation. As such, they inspired a sense of comfort and ease among worshipers, assuring them that "The saved did not have to worry about the lack of material wealth." 33 Charles Price Jones captured succinctly this euphoric purpose in his 1900 composition, “I’m Happy with Jesus Alone":

There's nothing so precious as Jesus to me;

Let earth with its treasures be gone;

I'm rich as can be when my Saviour I see;

I'm happy with Jesus alone. I'm happy with Jesus alone, I'm happy with Jesus alone; Tho poor and deserted, thank God, I can say I'm happy with Jesus alone. ${ }^{34}$

\section{Conclusion}

While scholars have long noted music's intimate connection with public worship, few have attempted a systematic analysis of exactly how sacred music accomplishes social purposes. In this paper, I have proposed one possible way to approach this largely neglected area of

\footnotetext{
${ }^{33}$ Ibid., 45.

${ }^{34}$ Charles Price Jones, “The History of My Songs," Journal of Black Sacred Music 2:2 (Fall 1988): 62.
} 
inquiry: applying Durkheim's four social functions of ceremonial ritual to sacred music. The illustrations above represent just a sample of the countless sacred songs that serve one or more of Durkheim's categories, and it is likely that further studies would reveal that nearly all of the world's sacred music can accomplish — to a greater or lesser extent - the disciplinary, cohesive, revitalizing, or euphoric potential of public worship.

Still, these categories do not cover all of the possible social uses of sacred music. Religious studies scholar Catherine Bell, for instance, noted that the performance of ceremonial ritual can reinforce social hierarchies, ${ }^{35}$ and anthropologist Ellen Dissanayake has written on the ability of ritual music to control and channel individual aggression within a community. ${ }^{36}$ Nevertheless, it is clear that Durkheim's analysis of ceremonial ritual offers a useful framework through which to examine the social value of sacred music.

\footnotetext{
${ }^{35}$ Catherine Bell, "Performance," in Critical Terms for Religious Studies, ed. Mark C. Taylor (Chicago: University of Chicago Press, 1998), 208.

${ }^{36}$ Ellen Dissanayake, "Ritual and Ritualization: Musical Means of Conveying and Shaping Emotion in Humans and Animals," in Music and Manipulation: On the Social Uses and Social Control of Music, eds. Steven Brown and Ulrich Volgsten (New York: Berghahn Books, 2006), 31-56.
} 


\section{Bibliography}

Alpert, Harry. Emile Durkheim and His Sociology. New York: Russell and Russell, 1961.

Bell, Catherine. "Performance," in Critical Terms for Religious Studies. Edited by Mark

C. Taylor. Chicago: University of Chicago Press, 1998.

Cook, Nicholas. A Guide to Musical Analysis. London: Oxford University Press, 1987.

Dickinson, Edward. "Oratorio Performance in Europe and America," in The American History and Encyclopedia of Music. Edited by W. L. Hubbard. New York: Irving Squire, 1909.

Dissanayake, Ellen. "Ritual and Ritualization: Musical Means of Conveying and Shaping Emotion in Humans and Animals," in Music and Manipulation: On the Social Uses and Social Control of Music. Edited by Steven Brown and Ulrich Volgsten. New York: Berghahn Books, 2006.

Durkheim, Émile. "Concerning the Definition of Religious Phenomena," in Durkheim on Religion. Edited by W. F. K. Pickering. London: Routledge and Kegan Paul, 1975.

. The Elementary Forms of Religious Life. Trans. by Carol Cosman.

New York: Oxford University Press, 2001.

Ellwood, Robert S. Introducing religion from Inside and Outside, 2nd ed. Upper Saddle River, NJ: Prentice Hall, 1983.

Fuller, Robert C. Spiritual, but not Religious: Understanding Unchurched America. New York: Oxford University Press, 2001.

Hayford, Jack. Worship His Majesty. Waco, TX: World Book Publisher, 1987.

Heuman, Fred S., trans. "Prayer and the Sheliach Tzibbur During the Holocaust." Journal of Jewish Music and Liturgy 3 (1985-86): 55-56.

Honigsheim, Paul. Sociologists and Music: An Introduction to the Study of Music and Society. New Brunswick, NJ: Transaction Publishers, 1989.

Jacobson, Sam L. "The Music of the Jews." Music: A Monthly Magazine 14 (1898): 412-16.

James, William. The Varieties of Religious Experience. New York: Mentor Books, 1958.

Johnstone, Ronald L. Religion in Society: A Sociology of Religion. Upper Saddle River, NJ: Prentice Hall, 1997. 
Jones, Charles Price. “The History of My Songs.” Journal of Black Sacred Music 2:2 (Fall 1988): 62.

Lukes, Steven. Emile Durkheim: His Life and Work. New York: Harper and Row, 1972.

Marini, Stephen A. Sacred Song in America: Religion, Music, and Public Culture. Urbana and Chicago: University of Illinois Press, 2003.

Merriam, Alan P. "The Arts and Anthropology," in Anthropology and Art: Readings in Cross-Cultural Aesthetics. Edited by Charlotte M. Otten. Austin, TX: University of Texas Press, 1971.

Newton, R. Heber. The Mysticism of Music. New York: Putnam, 1915.

Nulman, Macy. Concepts of Jewish Music and Prayer. New York: Yeshiva University Press, 1985.

Pratt, Waldo S. "Religion and Music," in The World's Parliament of Religions. Edited by John Henry Barrows. Chicago: The Parliament Publishing Co., 1893.

Preus, J. Samuel. Explaining Religion: Criticism and Theory from Bodin to Freud. Atlanta, GA: Scholars Press, 1996.

Saliers, Don E. Music and Theology. Nashville, TN: Abingdon Press, 2007.

Taylor, Clarence. The Black Churches of Brooklyn. New York: Columbia University Press, 1994.

Towns, Elmer. Putting an End to Worship Wars. Nashville, TN: Broadman and Holdman Publishers, 1997.

Wren, Brian. Praying Twice: The Music and Words of Congregational Singing. Louisville, KY: Westminster John Knox Press, 2005. 